\title{
The perception of municipal managers on the management of urban solid waste
}

\author{
Ana Luiza Bertani Dall' Agnol' \\ Larissa Loebens" \\ Carolina Faccio Demarco"II \\ Mélory Maria Fernandes de Araujo'v \\ Diuliana Leandrov \\ Andréa Souza Castrovı \\ Maurizio Silveira QuadrovII
}

\section{Abstract}

The solid waste management in Brazil is supported by the National Solid Waste Policy (PNRS) and, in the case of municipal waste, the responsibility lies for municipalities. The aim of this research was to describe the perception of the managers of the municipalities of the South Region of Rio Grande do Sul regarding solid waste management. Through the application of a questionnaire addressed to the managers of the cities, difficulties were identified: the lack of technical and financial resources for the implementation of the instruments proposed by the PNRS, such as the Municipal Integrated Solid Waste Management Plans (PMGIRS) and selective collection of municipal solid waste. In addition, there were found problems as the lack of collaboration of the population for the functioning of collection systems and difficulties in the insertion of cooperatives and associations of collectors of recyclable materials within the management cycle. Despite the problems faced, managers recognize the importance of integrated solid waste management to improve management and planning of actions, to promote environmental quality and public health and as a method to reduce costs and raise funds.

Keywords: Municipal Plan for Integrated Management of Solid Wastes; Environmental management; Public policy 


\section{Introduction}

Population growth associated with the urbanization process and the intense use of natural resources are the ideal combination for the planet's environmental imbalance. The generation of municipal Urban Solid Waste (MSW) is one of the most serious problems of the present time, making this a difficulty found by cities over the decades (SANTIAGO; DIAS, 2012).

In this context, the final collection and destination of generated MSW presents a great challenge to the municipalities due to the large amount generated, the financial expenses related to its management and the impacts caused to the environment and the population health (GONÇALVES et al., 2013).

According to the Brazilian Solid Waste Survey, carried out by ABRELPE in 2017, the total MSW generation in the country was 78.4 million tons. The collection coverage index was $91.2 \%$, which indicates that approximately 6.9 million tons of waste were not collected and, therefore, were unknown destined and probably inappropriate (ABRELPE, 2018).

After more than 20 years of discussion in the National Congress, in 2010, the Law $\mathrm{N}^{\circ}$. 12,305 established the National Solid Waste Policy (PNRS), which brought several advances to the management of solid waste in Brazil (BRASIL, 2010). The PNRS presents a new approach to integrated management of solid waste, prioritizing integrated planning, and sets the conditions for achieving PNRS aims within each federated entity (OLIVEIRA; GALVÃO JUNIOR, 2016).

The Municipal Solid Waste Management Plan (PMGIRS) is included in the PNRS as a tool for the solid waste management and conditioning for the Federal District and the Municipalities to have access to Union resources, destined to the enterprises and services related to urban cleaning and the management of these wastes (BRASIL, 2010).

Despite the numerous benefits and the legal requirement, the municipalities presents difficulties in the elaboration of Municipal Plans for Integrated Solid Waste Management. In this context, it is essential to question the impasses faced by the municipalities, as well as to understand the motivation of the public administrators in the elaboration of the plans. Thus investigating whether they are elaborated only with a view to the legislation compliance or because they understand the real benefits that can be achieved by using them as a management tool (LISBOA et al., 2013).

When considering the product life cycle, the concept of shared responsibility aims the correct disposal of solid waste, thus reaching all the actors involved in the productive and consumption chain (OLIVEIRA; GALVÃO JÚNIOR, 2016). Therefore, the recognition of shared responsibility is essential for the advance of waste management in the country so that not only public sphere held the responsibility for urban solid waste (RIBEIRO, 2012).

In this context, the aim of this work was to describe the perception of the municipal managers of the South
Region of Rio Grande do Sul regarding the management of Urban Solid Waste, as required in the PNRS. In addition, the aim was to verify the progress of the elaboration and implementation of the Municipal Plan of Solid Waste in each locality, besides identifying the difficulties faced in this process.

\section{Methodology}

This work has a descriptive character, as it was intended to observe, describe and explore analytically the proposed theme, through a case study involving 17 municipalities, identified in Figure 1, located in the South Region of the State of Rio Grande do Sul. The municipalities were: Arroio do Padre, Arroio Grande, Bagé, Caçapava do Sul, Canguçu, Capão do Leão, Herval, Lavras do Sul, Morro Redondo, Pedro Osório, Pelotas, Pinheiro Machado, Piratini, Rio Grande, São José do Norte, São Lourenço do Sul e Sertão Santana.

The municipal public managers responsible for solid waste management in the targeted municipalities were contacted by the study via e-mail and telephone. The managers were invited to participate in a Training Course for the Implementation of Municipal Plans of Solid Waste held at the Federal University of Pelotas.

During the course, a questionnaire with directed questions and open questions was applied to the municipal managers in order to understand the situation of solid waste management in the municipalities and the perception of the interviewees regarding the theme. The questionnaire was applied through a face-to-face interview consisting of 25 questions. The average duration of the interview was 30 minutes and the responses were recorded in writing by the interviewer.

The interview is a strategy for the data collection, in which the researcher seeks information about ideas, beliefs, ways of acting, behavior or intentions, conscious or unconscious motives and feelings in the speeches of social actors (MINAYO, 1998). For Lima et al. (2015), this is one of the techniques most used in the field work and consists of a process of social interaction between subjects, one that acts in the process and another that studies the process.

The answers obtained were tabulated using the Microsoft Office Excel 2010 program and analysed for content. This analysis was carried out in order to identify the key points of the answers in the open questions (when the respondent described a fact, for example).

According to Bardin (1979), the analysis of the content of the interviews aims to describe, through systematic and objective procedures, the messages recorded, aiming to indicate the quantitative indicators or not that allow the inference of results and understandings regarding the conditions of production and receiving these messages. For the analysis of content, the thematic analysis technique was adopted, which consists of discovering the sense nuclei that compose a communication, whose manifestation or repetition has meaning for the analytical 
Figure 1 - Target municipalities of South Region of Rio Grande do Sul

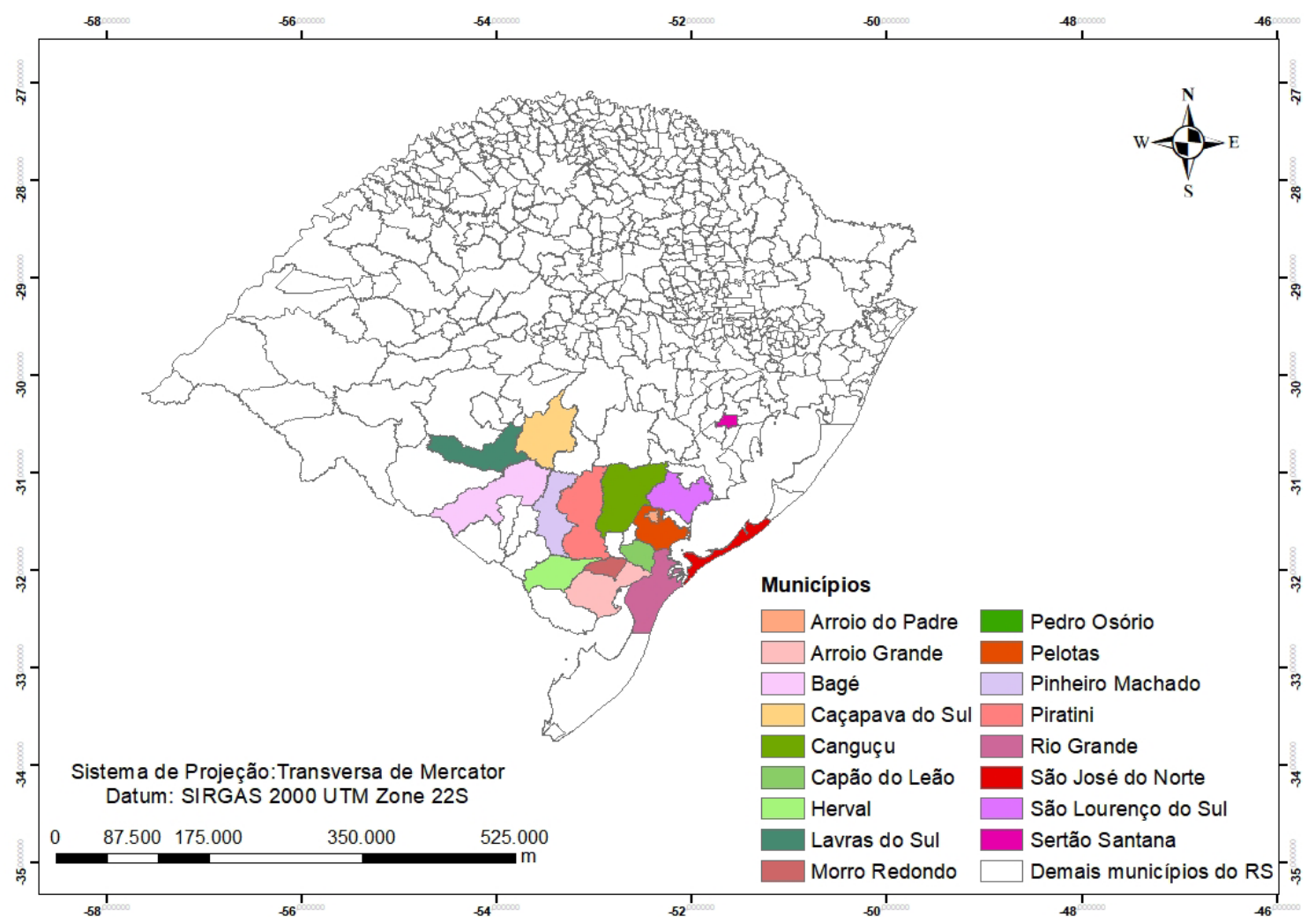

objective aimed. The thematic analysis, according to the author, lends itself to the study of the motivations, attitudes, values, beliefs and inclinations of the interviewees.

The nuclei approach were established in 3 thematic axes related to: the elaboration and implementation of the Municipal Plans for Integrated Solid Waste Management in the municipalities; solid waste management situation; as well as the managers' perception regarding environmental impacts.

\section{Results}

The elaboration of the Municipal Plan for Integrated Solid Waste Management (PMGIRS) by the municipalities is necessary so that municipalities can be provided with federal government resources for public cleaning and solid waste management projects or be benefited by incentives and financings of federal credit entities or promotion for this purpose (BRASIL, 2010). Among the municipalities analysed in this study, only $18 \%$ were reported having the PMGIRS finalized, the other municipalities do not have a plan or they are in the process of elaboration $(82 \%)$.

From the total number of municipalities that declared not having PMGIRS implemented, $78.6 \%$ stated that the plans are being drafted. The PMGIRS elaboration phase varies among municipalities, $45 \%$ said they are in the stage of contracting the team that will carry out the plan, $18 \%$ in the diagnostic stage, $27 \%$ are finalizing the plan and $9 \%$ of the interviewees did not know how to report the stage elaboration of the PMGIRS in their respective municipalities.

It should be emphasized that the elaboration of municipal plans has a great influence on the effectiveness of municipal solid waste management planning. The population has an important role in the PMGIRS planning and implementation process, acting as a partner in the elaboration of the plan and then monitoring and claiming the results that were planned (SILVA, 2012).

For the effective elaboration of PMGIRS, it is necessary to understand the integrated solid waste management concept. When questioned about what they consider as an "integrated solid waste management", the cooperation between public power, population and companies in the effective execution of the PNRS was cited by $88 \%$ of the managers. The reduction, reuse and recycling of waste was marked by $24 \%$; the final disposal of adequate solid waste was related by $18 \%$ of respondents; and finally, the option "support for a good functioning of the PNRS"; and the option "integrated management of all waste classes and logistics adjustment from start to finish" were cited by $6 \%$ of managers.

Municipal managers were asked about the importance and benefits of implementing PMGIRS for municipalities, as presented in Table 1. Improvement in solid waste management in municipalities (53\%), planning of actions $(47 \%)$, urban solids waste management $(47 \%)$ and public health improvement $(24 \%)$ were the most cited benefits, 
other items were raised to a lesser extent.

Table 1 - Benefits of implementing PMGIRS in municipalities

\begin{tabular}{l|c}
\hline Aspect & $\begin{array}{l}\text { Frequency of answers } \\
\text { (\%) }\end{array}$ \\
\hline Improving management & 43 \\
Planning of actions & 47 \\
Proper management of MSW & 24 \\
Improvement of public health & 12 \\
Selective collect & 12 \\
Fund-raising & 6 \\
Reduction of public spending & 6 \\
Avoid flooding & 6 \\
Ensure the inclusion of waste & 6 \\
pickers & 6 \\
Reduction of polluting & \\
potential & \\
Compliance with legislation & \\
\hline
\end{tabular}

In this context, the observations meet the aims of the PNRS, which are the protection of public health and environmental quality, the incentive to the recycling industry, the integrated management of solid waste, the articulation between the different spheres of public power and continuous technical training in the solid waste sector, among others (BRAZIL, 2010). Thus, the PMGIRS, as instruments of this Policy, should be elaborated with the purpose of meeting and achieving these aims in short, medium and long term.

The municipal managers were also questioned about the obstacles in the elaboration of the Municipal Plan of Integrated Management of Solid Waste (PMGIRS) in their municipalities. The question allowed more than one answer per interviewee, as well as the insertion of other problems faced by the municipalities in the elaboration of PMGIRS. The lack of technical staff $(76 \%)$, lack of financial resources (53\%), lack of cooperation between the parts involved (47\%), lack of data (41\%), lack of knowledge about legislation (35\%) and the lack of time (24\%) were the greatest difficulties cited by the municipalities for the elaboration of PMGIRS.

In a study carried out by the Environment Department of the State of São Paulo, with data obtained through the training project "Integrated Municipal Waste Management (GIREM)", several difficulties faced by managers in the elaboration of PMGIRS in the State of São Paulo were pointed out. The difficulties detected are similar to those mentioned by the municipal managers questioned in this research, among them: lack of technical capacity of municipal managers (18.2\%), unavailability of financial resources (15.1\%), lack of information and availability of data in the prefecture (13.2\%) and unawareness of the importance of participating in the process $(10.7 \%)$
(Government of the State of São Paulo, 2013).

Costa and Pugliesi (2018) in their study pointed out the technical capacity of municipal managers as the greatest difficulty in the elaboration of the Municipal Plans for Integrated Management of Solid Waste. In order to overcome the difficulty related to the lack of technical capacity and to assist the managers, several public agencies produced manuals and other materials that can be used as reference for the elaboration of the municipal plans.

Among the municipalities that were present in the course, $18 \%$ already have PMGIRS. The managers of these municipalities were asked about the main difficulties faced in the implementation process of the municipal plan. This question of the study also allowed managers to point out all the difficulties found, without limiting the number of alternatives.

Among the main difficulties pointed out by the managers for the implementation of the municipal plan in its municipalities, it can be highlighted the lack of financial resources and the difficult of contracting sustainable companies, both of which were mentioned by $67 \%$ of the municipalities that have already implemented the plan. The approval of the plan; the lack of environmental education by the population; supervision and technologies related to the treatment and disposal of waste were obstacles faced by $33 \%$ of these municipalities.

Lisboa et al. (2013), when analysing the challenges of municipal sanitation planning in 15 small municipalities in the Mata de Minas Gerais Zone, found as main difficulties in the elaboration of the Municipal Plans of Basic Sanitation: the lack of financial resources and the limitation on the professional qualification and municipal technical capacity. Other factors such as the integration of municipalities that are part of the basic sanitation area and political issues were detected as problems raised by the managers interviewed in the planning of actions.

The municipalities that have already implemented the PMGIRS were asked about the initiatives adopted to solve the problems faced during drawing up the plan. The elaboration of the integrated management plan along with education, mobilization and social participation were solutions indicated by $67 \%$ of the managers as fundamental actions to enable an efficient implementation of the plan. The inclusion of recyclable waste pickers to act in the selective collection, sorting, classification, processing and commercialization of waste generated was pointed out by $33 \%$ of the interviewees as alternatives adopted in the PMGIRS implementation process.

It should be noted that the socio-participatory integration of waste pickers of recyclable materials is foreseen and supported by the PNRS, and the municipalities that implement selective collection with the participation of cooperatives or other forms of association of recyclable and reusable material waste pickers formed by low income population will be prioritized in accessing the resources of the Union (BRAZIL, 2010). In addition, when they become members of associations and cooperatives, these workers are characterized as service providers, which provides better working conditions, in addition to 
the increase for materials that are treated in the various production chains and, therefore, generate opportunities in many sectors.

The correct waste management is a fundamental strategy for the preservation of the environment and for the promotion of public health. Among the risks associated with inadequate waste disposal, it can be cited the impacts in soil, water and air quality, considering the emissions of volatile organic compounds, presence of pesticides, solvents and heavy metals (GIUSTI, 2009), as well as generating environments propitious for the proliferation of vectors and other disease-transmitting agents (GOUVEIA, 2012). The evaluation of the perception of environmental risks due to the lack of PMGIRS was evaluated, and the main harms aspects pointed out by the managers were negative environmental impacts (82\%), public health problems (71\%), floods (65\%), increased of public financial resources (53\%), visual pollution (18\%) and degradation of public areas (6\%).

Regarding the collection of municipal solid waste, the largest part of the municipalities contracted outsourced companies (59\%), while the rest provided direct service (41\%). The main final destination of waste adopted by the municipalities is in contracted landfills (88\%), being them: the landfill of Candiota/RS (60\%), Minas do Leão/ RS (27\%), Rio Grande/RS (7\%) and Santa Maria/RS (7\%). For this activity, $59 \%$ of the municipalities reported the presence of a waste transhipment station, which are intermediate destination points of the collected residues, depending on the distance between the collection area and the landfill.

When asked about the evaluation of the waste collection system of their municipalities, most managers $(41 \%)$ assigned grade 6 (on a scale of 0 to 10 ), followed by $18 \%$ assigning grades $8 ; 18 \%$ assigning grade 5 ; and $12 \%$ assigning grade 7 to the collection system. The other interviewees rated below grade 5, demonstrating that there is still a great demand for improvement in sanitation service provision. It should be noted that only $59 \%$ of the municipalities interviewed have already performed the qualitative and quantitative characterization of the urban waste generated in the city, which are essential for integrated waste management, since they allow a characterization of the current scenario and effective long-term planning. It is only after knowing the quantity and the composition of the MSW that the procedures and techniques can be defined to manage and treat the wastes of each locality (ASSAMOILA; WRYSHYN, 2012).

The managers were asked about the problems in household waste collection. (Figure 1). The main obstacles detected were the lack of environmental education (71\%), lack of selective collection, including absence or inefficiency (35\%), and with the same percentage, there were cited the inadequate vehicles $(24 \%)$, lack of recycling bins $(24 \%)$ and inadequate disposal of MSW (24\%). The other aspects pointed out were found to a lesser extent.

After the verification of several problems related to urban household collection, it can be highlighted the presence of degraded areas by the inadequate disposal of solid wastes in the municipalities, and from the perception of the managers, the existence of impacted areas were detected in $82 \%$ of the studied areas. Among these municipalities that identified affected areas, the typologies of these areas were described as: old landfills or dumps $(50 \%)$, uninhabited or irregular land $(21 \%)$, rural areas (14\%), drainage systems (14\%) and in smaller percentage: peripheries (7\%) and gravels $(7 \%)$.

Considering the large percentage of problems found in selective collection (35\%) affecting the urban household collection of the municipalities in question (Figure 1), it

Figure 1 - Main problems in the urban household collection according to the interviewed managers

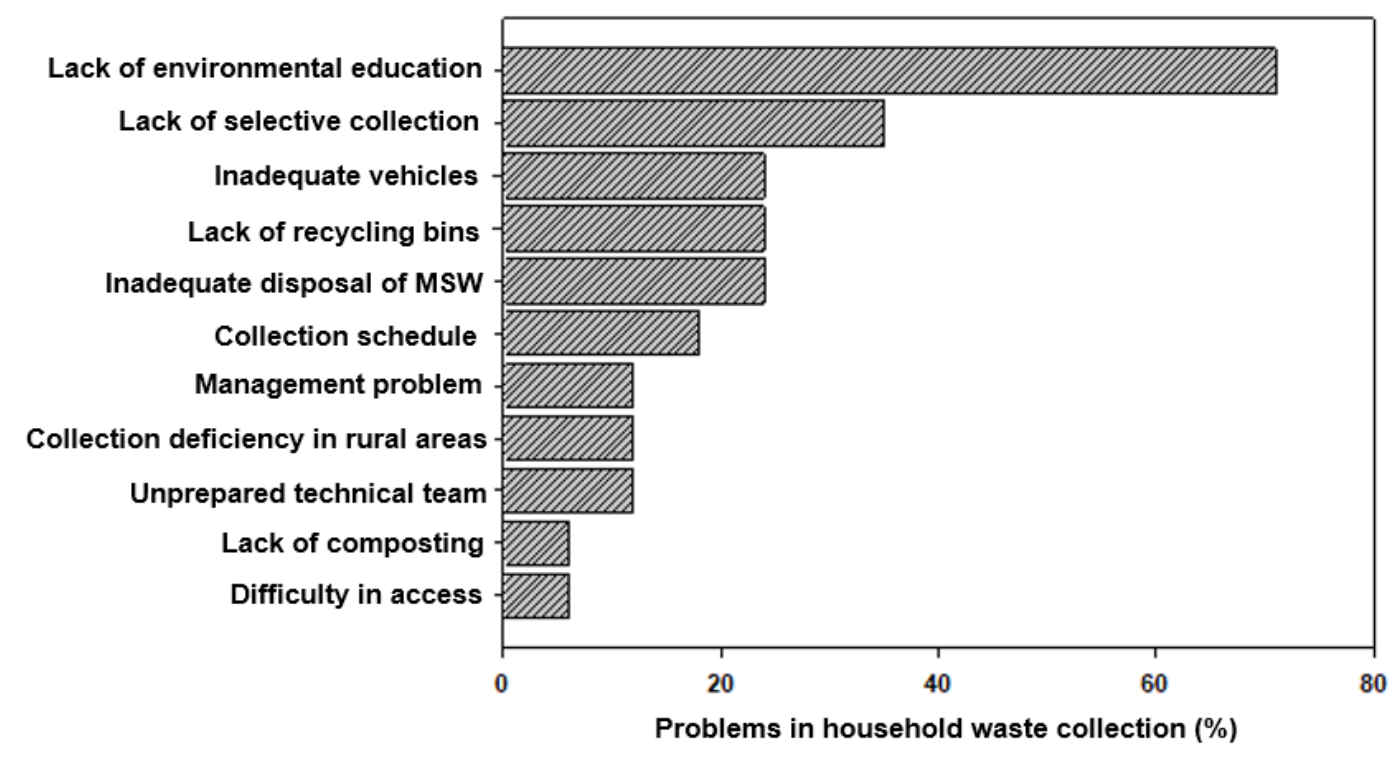


was found that only $53 \%$ of the municipalities present a selective collection system implemented. Among them, most performs these activities between 2 to 5 years $(56 \%$ of municipalities), $33 \%$ carried out selective collection activities for more than 5 years and $11 \%$ for less than 2 years. Thus, it is considered that the relatively recent implementation time of selective collection by most of the municipalities could be contributing to possible problems of inefficient operation and collection, issues that can be evaluated and remedied through promoted actions by PMGIRS.

Another relevant issue is the scope of selective collection. Regarding the municipalities that claimed to have selective collection, only $56 \%$ of them reported the presence of the system in the entire urban area, and this number was even smaller when questioned about the rural area, where only $44 \%$ reported having the selective waste collection in its rural area.

In addition to the low coverage of selective collection verified, another problem was detected in relation to the evaluation of the efficiency of the selective collection system. Most municipalities reported having a poor or inefficient system ( $44 \%$ ), followed by $22 \%$ with a regular evaluation, and only $33 \%$ rated the system as being good. The need for incentives for more municipalities in the Southern Region to adopt the system of selective collection of solid wastes, as well as the need to universalize and promote the quality of operation of the services is indispensable. Therefore, prior planning is necessary to adopt the best implementation strategies so that the benefits of an efficient selective collection can be achieved (MIRANDA; MATTOS 2018).

In relation to the difficulties reported for the adhesion of selective collection (Table 2), it can be seen that, once again, environmental education stands out as an aspect of greater relevance among the managers interviewed. According to Pinto and Modelli (2017), the correct segregation of waste in the generating source, when carried out adequately and in a planned way, contributes to the fact that only waste that cannot be treated goes to final disposal in landfills; reduces costs of collection and sorting of recyclable materials, being, therefore, a commitment of all the social sectors involved.

Subsequently, it was verified that the lack of cooperative or association between the municipality and the collectors also makes difficult the implementation of a system of selective collection of solid waste, since these agreements guide and provide the necessary support so that the waste pickers can segregate and sale the material obtained. The other reported aspects were related to management's lack of interest, as well as the lack of human resources (technical staff and secretaries) and financial resources (Table 2).

More specifically, when asked about the number of cooperatives and associations of waste pickers in each municipality, it was found that a significant number of municipalities did not present any cooperative or association (35\%). The distinction between the two institutions (cooperatives and associations) is basically due to the nature of each one, since the associations have the charac- ter of social assistance and protection of class interests, and cooperatives have an essentially economic purpose. Among the municipalities studied, $41 \%$ stated that they only present one cooperative, $6 \%$ stated presenting two cooperatives, $12 \%$ stated having only one association, and $6 \%$ stated having four associations.

Table 2 - Difficulties reported by the municipality for the adhesion of the solid waste selective collection.

\begin{tabular}{l|c}
\hline Aspect reported & $\begin{array}{l}\text { Frequency of responses } \\
\text { (\%) }\end{array}$ \\
\hline $\begin{array}{l}\text { Lack of environmental } \\
\text { education }\end{array}$ & 47 \\
$\begin{array}{l}\text { Cooperative/association } \\
\text { formation }\end{array}$ & 35 \\
$\begin{array}{l}\text { Lack of interest of the } \\
\text { current administration }\end{array}$ & 18 \\
$\begin{array}{l}\text { Lack of financial resources } \\
\text { Lack of vehicles }\end{array}$ & 18 \\
$\begin{array}{l}\text { Lack of secretaries } \\
\text { Lack of technical team }\end{array}$ & 12 \\
$\begin{array}{l}\text { Lack of area for sorting } \\
\text { recycling material }\end{array}$ & 6 \\
$\begin{array}{l}\text { Expansion of the municipality } \\
\text { Unprepared team of waste } \\
\text { pickers }\end{array}$ & 6 \\
$\begin{array}{l}\text { Existence of only voluntary } \\
\text { collection points }\end{array}$ & 6 \\
Uninformed & 6 \\
\hline
\end{tabular}

Regarding the presence or absence of a waste sorting area, only $47 \%$ of the municipalities answered that there is a sorting center in operation. Despite the numerous benefits with the inclusion of cooperatives and associations of waste pickers (such as the generation of employment opportunities and better distribution of profits obtained through recycling), it can be seen the deficiency of implementation of these centers of great socioeconomic importance.

Regarding the social aspects, Pereira et al. (2018) emphasize the need for social inclusion of waste pickers of recyclable materials in the integrated management of solid urban waste, since this inclusion promotes the process of formalization of the category, through the creation of cooperatives and associations. However, the authors also point out that the lack of an organization by these waste pickers reflects directly in the absence of partnerships between the local public power and these workers.

In the urban cleansing theme, the interviewees were asked about the main problems faced (Table 3). In this sense, problems such as clandestine waste disposal (82\%), proliferation of vectors $(41 \%)$ and bad odor $(35 \%)$ are cited in greater proportions; these aspects demonstrate 
the managers' perception regarding the waste problem, considering that the environmental impacts are also cited as a result of inefficient waste management and urban cleaning.

Table 3 - Difficulties reported by managers on cleaning of the urban area.

\begin{tabular}{l|c}
\hline Aspect reported & \multicolumn{2}{|l}{$\begin{array}{l}\text { Frequency of responses } \\
\text { (\%) }\end{array}$} \\
\hline Clandestine waste disposal & 82 \\
Proliferation of vectors & 41 \\
Bad odor & 35 \\
Lack of collection & 24 \\
Population growth & 24 \\
Lack of trash cans & 12 \\
Lack of environmental & 12 \\
education & \\
Lack of pruning trees & 6 \\
Lack of appropriate waste & 6 \\
disposal facilities & 6 \\
Lack of human and financial & \\
resources & \\
\hline
\end{tabular}

For Demajorovic and Migliano (2013), a point of great relevance in the approval of PNRS in Brazil was the obligation to implement reverse logistics and the recognition of the need for shared responsibility among all sector involved in the different production chains, including, in addition to manufacturers, the public sector, trade, consumers and waste pickers' organizations.

Thus, in relation to the reverse logistics in the municipalities interviewed, it was found that $47 \%$ presented reverse logistics programs related to batteries, $41 \%$ of electronic material, $35 \%$ of tires, $18 \%$ of fluorescent lamps, $12 \%$ of packaging of agrochemicals and $6 \%$ of oils and lubricant packages.

Couto and Lange (2017) stated that the current legislation has driven the development of reverse logistics systems in Brazil and Europe, making the productive sectors to re-evaluate the life cycles of their products. According to the authors, this motivation has the potential to lead to the cooperative operationalization between different links of the productive chain, being, in this way, a competitive strategy of sustainable and profitable businesses.

\section{Conclusions}

The managers of the municipalities of the southern region of Rio Grande do Sul understand the importance of the implementation of the Integrated Solid Waste Management Plan for the improvement of public sanitation services as the urban cleaning and solid waste management. It is essential thus for guaranteeing an efficient management and planning of actions, and the promotion of public health.

In this context, the observation of the problems faced, especially in relation to the collection systems and the lack of awareness on the part of the population, shows the managers' perception regarding the insufficiency of the services offered by the municipalities in the solid waste management sector. In addition, it was detected the awareness of the risks associated with the environment as a consequence of this inefficient management.

Despite the importance of the establishment and the requirement of the elaboration of PMGIRS by the municipalities, the public managers find bureaucratic difficulties and a lack of technical and financial resources for the elaboration of municipal plans. This fact demonstrates that the institution of policies and legislation are not necessarily accompanied by the development and training of the municipalities for them to be efficient applied.

The lack of technical and financial support to the municipal public sectors, therefore, results in a weak adherence of the National Solid Waste Policy, and leads to unsatisfactory and late elaboration and implementation of Plans that are often fulfilled only for legislation requirements.

\section{References}

ABRELPE - Associação Brasileira de Empresa de Limpeza Pública e Resíduos especiais. Panorama dos Resíduos Sólidos no Brasil, 2017 [Internet]. Available from: http://abrelpe.org.br/download-panorama-2017/.

ASSAMOI, B, LAWRYSHYN, Y. The environmental comparison of landfilling vs. incineration of MSW accounting for waste diversion. Waste Management, 2012; 32(5): 1019-1030.

BARDIN L. Análise de conteúdo. Lisboa: Edições 70; 1979.

BRASIL. Lei ${ }^{\circ} 12.305$ de 02 de agosto de 2010. Brasília, 2010. Institui a Política Nacional de Resíduos Sólidos. Diário Oficial da União (Brasília) 2010 agosto 02.

COSTA AM, PUGLIESI E. Análise dos manuais para elaboração de planos municipais de gestão integrada de resíduos sólidos. Engenharia Sanitária e Ambiental, 2018;23(3):509-516.

COUTO MCL, LANGE LC. Análise dos sistemas de logística reversa no Brasil. Engenharia Sanitária e Ambiental, 2017; 22(5): 889-898.

DEMAJOROVIC J, MIGLIANO JEB. Política Nacional de Resíduos Sólidos e suas implicações na cadeia da logística reversa de microcomputadores no brasil. Gestão \& Regionalidade, 2013; 29(87):64-80. 
GONÇALVES MA, TANAKA AK, AMEDOMAR, AA. A destinação final dos resíduos sólidos urbanos: alternativas para a cidade de São Paulo através de casos de sucesso. Future Studies Research Journal, 2013; 5(1), 96-129

GIUSTI L. A review of waste management practices and their impact on human health. Waste Management, 2009; 29(8), 2227-2239.

GOUVEIA, N. Resíduos sólidos urbanos: impactos socioambientais e perspectiva de manejo sustentável com inclusão social. Ciência \& Saúde Coletiva, 2012; 17(6), 1503-1510.

GOVERNO DO ESTADO DE SÃO PAULO. Gestão Integrada de Resíduos Sólidos Municipais: Plano Municipal de Gestão Integrada de Resíduos Sólidos, 2013. [Internet]. Available from: http://www.ambiente. sp.gov.br/cpla/residuos-solidos/projeto-de-apoio-agestao-municipal-de-residuos-solidos-girem/

LIMA KWS, ANTUNES JLF, SILVA ZP. Percepção dos gestores sobre o uso de indicadores nos serviços de saúde. Saúde \& Sociedade, 2015;24(1):61-71.

LISBOA SS, HELLER L, SILVEIRA RB. Desafios do planejamento municipal de saneamento básico em municípios de pequeno porte: percepção dos gestores. Engenharia Sanitária e Ambiental, 2013;18(4):341-348.

MINAYO MCS. O desafio do conhecimento: pesquisa qualitativa em saúde. São Paulo: Hucitec; 1998.

MIRANDA NM, MATTOS UAO. Revisão dos modelos e metodologias de coleta seletiva no Brasil. Sociedade \& Natureza, 2018; 30(2), 1-22.

OLIVEIRA TB, GALVÃO JUNIOR AC. Planejamento Municipal na organização da coleta seletiva. Engenharia Sanitária e Ambiental,2016; 21(1): 55-64.

PEREIRA SS, CURI RC, CURI WF. Uso de indicadores na gestão dos resíduos sólidos urbanos: parte II - uma proposta metodológica de construção e análise para municípios e regiões: aplicação do modelo. Engenharia Sanitária e Ambiental, 2018; 23(3): 485-498.

PINTO RAFR, MONDELLI G. Potencial de recuperação de recicláveis em um condomínio residencial de grande porte de São Caetano do Sul. Engenharia Sanitária e Ambiental, 2017; 22(4): 647-656.

RIBEIRO WA. A relação entre os marcos regulatórios do saneamento básico e dos resíduos sólidos. In: Jardim A, Yoshida C, Machado Filho JV, editors. Política nacional, gestão e gerenciamento de resíduos sólidos. São Paulo: Manole; 2012. p.541-560.
SANTIAGO LS, DIAS SMF. Matriz de indicadores de sustentabilidade para a gestão de resíduos sólidos urbanos. Engenharia Sanitária e Ambiental, 2012;17(2): 203-212.

SILVA FJA. A natureza dos planos municipais de saneamento é influenciada pelas instituições elaboradoras?: Um estudo comparativo em três municípios de Minas Gerais [dissertation]. Belo Horizonte: Saneamento, Meio Ambiente e Recursos Hídricos/UFMG, 2012.

\section{Contribuição dos autores:}

Ana Luiza Bertani Dall' Agnol

Aquisição, análise ou interpretação de dados; redigiu o trabalho ou realizou uma revisão substancial.

Mélory Maria Fernandes de Araujo

Aquisição, análise ou interpretação de dados; redigiu o trabalho ou realizou uma revisão substancial.

Larissa Loebens

Aquisição, análise ou interpretação de dados;

Andréa Souza Castro

Aquisição, análise ou interpretação de dados;

Diuliana Leandro

Aquisição, análise ou interpretação de dados;

Carolina Faccio Demarco

Aquisição, análise ou interpretação de dados;

Maurizio Silveira Quadro

Aquisição, análise ou interpretação de dados; redigiu o trabalho ou realizou uma revisão substancial. 